\title{
GALVOS IR KAKLO GLEIVINĖS MELANOMA: KLINIKINIS ATVEJIS IR LITERATŪROS APŽVALGA
}

\author{
Nora Šiupšinskiene் $\dot{e}^{1,2}$, Vytautas Junčys ${ }^{3}$, Evaldas Padervinskis ${ }^{2}$, Sigutė Norkiene் $\dot{1}^{1,4}$ \\ ${ }^{1}$ Klaipèdos universitetas, Sveikatos mokslu fakultetas, ${ }^{2}$ Lietuvos sveikatos mokslu universiteto \\ Medicinos akademijos Ausu, nosies ir gerklès ligu klinika, ${ }^{3}$ Respublikinè Klaipédos ligoniné, \\ ${ }^{4}$ Klaipèdos jürininku ligoninè
}

Raktažodžiai: galvos gleivinès melanoma, kaklo gleivinès melanoma, spindulinè terapija, chirurgija, hadrono terapija, chemoterapija.

\begin{abstract}
Santrauka
Gleivinès melanoma - tai retas, labai agresyvus bei blogos prognozès navikas, dažniausiai nustatomas galvos ir kaklo srityje. Vienerių, trejų ir penkerių metų išgyvenamumas nuo $2000 \mathrm{~m}$. iki $2007 \mathrm{~m}$. Europoje buvo atitinkamai 63 proc., 30 proc. ir 20 proc. Prienosiniai ančiai, nosies ir burnos ertmè - sritys, kuriose dažniausiai nustatomi šio tipo navikai. Dažniausiai klinikinè išraiška ir simptomai yra nespecifiški. Chirurgija yra pagrindinis gydymo metodas. Norint kontroliuoti lokalų naviko plitimą, neretai pasitelkiama pooperacinè spindulinè terapija. Nepaisant skirtingos biologinès struktūros, gleivinès melanoma gydoma kaip odos melanoma. Daugumoje paskelbty naujausių mokslinių tyrimų gleivinès melanoma sergantys pacientai nebuvo įtraukti. Šiame straipsnyje pristatomas klinikinis retos patologijos atvejis bei literatūros apžvalga.
\end{abstract}

\section{Ivadas}

Galvos ir kaklo gleivinių melanomos (GKGM) sudaro 41 proc. visų gleivinès melanomų ir nuo 0,2 iki 8 proc. visų melanomų atvejų [1]. Dažniausia gleivinès melanomų lokalizacija yra galvos ir kaklo sritis - nosies, prienosinių ančių ir burnos ertmės gleivinè. Nuo 2000 m. iki 2007 m. Europoje nustatyti 2277 nauji atvejai. Pacientams nuo 25 iki $64 \mathrm{~m}$. amžiaus 5 metų išgyvenamumas buvo 23 proc., o vyresnių nei 65 m. - 19 proc. [2]. Didesnio progreso GKGM gydyme nebuvo pasiekta, tai atspindi 7 metų laikotarpiu nekintantys 5 metų išgyvenamumo rodikliai. Šiuo metu GKGM biologinè struktūra bei patogenezè, lyginant su odos melanoma, mažai žinoma [3]. Iprastai dauguma melanocitų randami odos epi- dermyje, dermoje bei akyse (ragenoje). Tačiau melanocitų galima rasti ir galvos - kaklo gleivinèje, ypač prienosinių ančių bei nosies srityje [4, 5]. Jų funkcija kol kas nèra aiški. Duomenų bazėse galima rasti tik kelias hipotezes, jų teigimu, melanocitai atlieka antimikrobinę bei imunologinę funkcijas $[6,7]$.

Šio darbo tikslas - aprašyti retą suaugusio žmogaus melanomos klinikinị atveji ir atlikti mokslo literatūros, skirtos galvos ir kako srities gleivinès melanomai, analizę.

\section{Klinikinis atvejis}

2012 m. vienoje Lietuvos gydymo ịstaigoje 69 metų L.M. pašalinta gleivinès melanoma iš nosies dugno kairejje landoje. $2014 \mathrm{~m}$. pacientè pakartotinai kreipèsi ị ligoninę dèl nosies užgulimo, dažnų išskyrų iš kairès landos. Apžiūros metu stebèta kaireje landoje apatinès kriauklès paviršiuje nelygumas, panašus i fibroepiteliomą. Imta biopsija ir gautas histologinio tyrimo atsakymas - melanoma. Nutarta pašalinti kairę apatinę nosies kriauklę kartu su dariniu medialiniame paviršiuje. Ištyrus pašalintus audinius, gautas histologinio tyrimo atsakymas - melanoma. Paciente buvo sekama ambulatoriškai.

2016 m. birželio mèn. L.M. kreipèsi ị gydymo ịstaigą dèl dažno pakraujavimo ir pasunkèjusio kvèpavimo pro nosị. Apžiūros metu stebèta kairè nosies landa, blokuojama netipiškais polipais, kurie kontaktiškai kraujavo. Atlikta veido daubų KT, pateikta išvada: kairèje nosies puseje heterogeninio tankio turinys, užpildantis kairiji žandinį antį, blokuojamas osteomeatinis kompleksas, masès iš dalies užpildo nosies landą bei priekines etmoidalines ląsteles. $2016 \mathrm{~m}$. liepos mèn. atlikta polipoetmoidotomija bei medialinè antrostomija kairèje. Operacijos metu nustatyti polipai, prisitvirtinę prie nosies dugno kairèje landoje bei medialinès kairiojo žandinio ančio sienos. Pašalinti audiniai ištirti histologiškai ir nustatyta melanoma, pašalinimas neradikalus.

2016 m. rugsèjo mèn. pacientè kreipèsi ị LSMU KK 

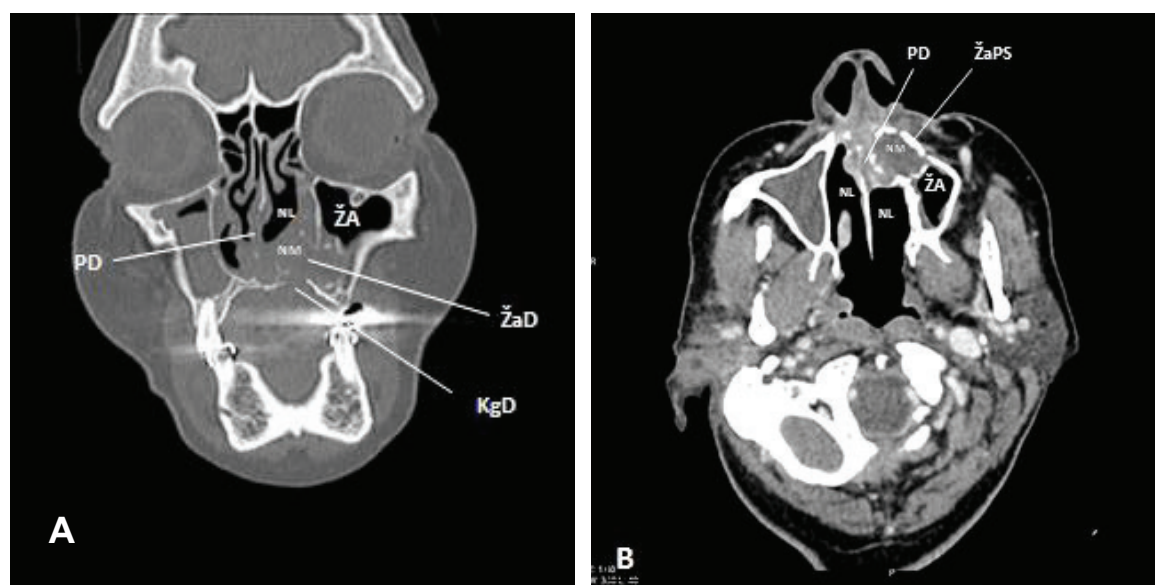

1 pav. Prienosinių ančių kompiuterinè tomograma (A - koronarinè projekcija, $\mathrm{B}$ - aksialinè projekcija, žandinis antis (ŽA): abipus apatinių nosies landų (NL) priekinèse dalyse matomos solidinio tankio navikinès masès (NM), sukeliančios kairio žandinio ančio priekinès sienos (ŽaPS), pertvaros (PD) ir kietojo gomurio kaulinę destrukciją (KgD). Pro kairio žandinio ančio medialinès sienelès apatinès dalies destrukcinę angą ( $\check{\mathrm{Z}} \mathrm{aD})$ audiniai prolabuoja ị žandinio ančio spindị priekinèje dalyje.

ANG ligų polikliniką, atlikta veido daubų $\mathrm{KT}$, pateikta išvada: abipus apatinių nosies landų priekinėse dalyse, gausiau kairèje, matomos solidinio tankio apie 3,0 x 2,0 cm dydžio masès, netolygiai kaupiančios kontrastinę medžiagą, sukeliančios viršutinio žandikaulio ir kietojo gomurio kaulinę destrukciją, pro kairio žandinio ančio medialinès sienelès apatinès dalies destrukcinę angą audiniai prolabuoja ị žandinio ančio spindị priekinèje dalyje (1 pav.).

2016 m. spalio mèn. atliktas PET KT tyrimas. Išvada - metaboliškai aktyvus navikinis procesas nosies ertmėje, kaklo limfmazgiai kontrasto nekaupia.

Paciente nukreipta gydytojo onkologo konsultacijai ir $2016 \mathrm{~m}$. spalio pabaigoje pradèta taikyti spindulinè terapija. Po taikyto gydymo $2017 \mathrm{~m}$. balandžio mèn. fibroendoskopijos metu nosies landos visiškai užblokuotos, kairès landos dugne stebimas darinys, deformuojantis landą. Faringoskopuojant stebima gomurio deformacija dinamikoje sumažèjusi. Pakartojus veido daubų KT, nustatyta progresuojanti nosies melanoma su veido kaulų destrukcija abipus. Konsiliume nuspręsta taikyti chemoterapinị gydymą dakarbazinu.

Po 5 chemoterapijos kursų pacientei pakartotinai atlikta veido daubų KT bei atlikta apžiūra poliklinikoje. Stebètos nosies melanomos masės dinamikoje sumažejusios apimties, veido kaulų destrukcija buvo be esminès dinamikos. Dabar pacientei baigiama 10 kursų chemoterapija.

\section{Literatūros apžvalga}

Klinika. GKGM esant nosies ir prienosinių ančių srityse, vyraujantys nusiskundimai nèra specifiški. Dažniausiai pasireiškia nosies obstrukcija, kraujavimas, skausmai veido srityje, rečiau - išverstakumas, oftalmoplegija, galvos skausmas, odos pakitimai [3-5]. Fibroendoskopija yra vienas iš dažniausiai naudojamų diagnostikos metodų, kurios metu galime pastebèti gleivinès pigmentacijos, infiltracinius pakitimus ar darinius. Pokyčiai ịprastai būna vienoje pusèje.
1 lentelè. Galvos ir kaklo gleivinės melanomos TNM klasifikacija [21].

\begin{tabular}{|l|l|}
\hline $\begin{array}{l}\text { Pirminis } \\
\text { navikas (T) }\end{array}$ & \multicolumn{1}{|c|}{ Požymiai } \\
\hline T3 & epitelis/pogleivis (gleivinės liga) \\
\hline T4a & $\begin{array}{l}\text { Pažeisti gilieji minkštieji audiniai, kremzlès, kau- } \\
\text { las ar dengianti oda }\end{array}$ \\
\hline T4b & $\begin{array}{l}\text { Pažeistos smegenys, kietasis dangalas, kaukolès } \\
\text { pamatas, galviniai nervai, kramtomieji raumenys, } \\
\text { miego arterija, prevertebralinis tarpas, mediasti- } \\
\text { numas }\end{array}$ \\
\hline Sritiniai limfmazgiai (N) \\
\hline Nx & Sritinių limfmazgių negalima įvertinti \\
\hline N0 & Sritiniuose limfmazgiuose metastazių nėra \\
\hline N1 & Sritiniuose limfmazgiuose metastazė yra \\
\hline Tolimosios metastazės (M) \\
\hline cM0 & Tolimujų metastazių nėra \\
\hline cM1 & Tolimosios metastazės yra \\
\hline pM1 & Tolimosios metastazės histologiškai patvirtintos \\
\hline
\end{tabular}

2 lentelè. Galvos ir kaklo gleivinès melanomos stadijos [21].

\begin{tabular}{|l|c|c|c|}
\hline Stadijos & Navikas & $\begin{array}{c}\text { Sritine } \\
\text { metastazè }\end{array}$ & $\begin{array}{c}\text { Tolimoji } \\
\text { metastazé }\end{array}$ \\
\hline III & $\mathrm{T} 3$ & $\mathrm{~N} 0$ & $\mathrm{M} 0$ \\
\hline IVa & $\mathrm{T} 3-\mathrm{T} 4 \mathrm{a}$ & $\mathrm{N} 1$ & $\mathrm{M} 0$ \\
\hline IVb & $\mathrm{T} 4 \mathrm{~b}$ & Bet kuri N & M0 \\
\hline IVc & Bet kuri T & Bet kuri N & M1 \\
\hline
\end{tabular}

Gleivinès melanomos be pigmentacijos pasitaiko ypač retai, tačiau ją diagnozavus, prognozè dèl stipraus agresyvumo prasta. Neretai aptinkamos ir satelitinès ląstelès, kurios nuo pagrindinio židinio gali būti nutolusios net iki $1 \mathrm{~cm}$. Dažniausiai nosies ertmejje gleivinès melanomos pasitaiko apatinès kriauklės ar šoninès sienos srityse $(43,1$ proc.), rečiau per- 
tvaros gleivinejje $(24,2$ proc.) [8]. Prienosiniuose ančiuose GKGM pasireiškia retai, tačiau labiau tikètinas gleivinès melanomos augimas žandiniuose ančiuose ir etmoidalinėse ląstelèse nei sfenoidaliniuose ar frontaliniuose ančiuose $[8,9]$.

Esant burnos ertmès gleivinès melanomai, vyraujantys nusiskundimai taip pat nèra specifiški, dažniausiai pacientai skundžiasi kraujavimu, skausmais, išopejjimais, dariniu burnos ertmèje. Kraujavimas ir išopejjimas labiau būdingas pažengusiai melanomos stadijai bei vertikalaus tipo augimui [10]. Faringoskopijos metu galime pastebèti hiperpigmentuotą infiltraciją, vyraujanti spalvų gama - juoda, ruda, pilka, rausva bei balkšva [11]. Nuo 10 iki 30 proc. atvejų nustatomos burnos gleivinès melanomos be pigmentacijos [12-14]. İtariant GKGM, privaloma išsami ANG organų apžiūra, nes darinys burnos ertmèje gali būti tik satelitinis augimas iš gretimos srities. Burnos ertmėje GKGM išskiriama 2 tipų: makulinis (plokščiojo tipo, invaziškumas ne vertikalus, o radialus) ir mazginis (būdingas įvairaus tipo augimas, dažnas išopejimas, tačiau auga ir egzofitiškai).

Itariant GKGM ryklëje, pacientas gali skųstis kraujavimu, pasunkejjusiu rijimu ar kvėpavimu. Literatūroje galima rasti tik kelis pavienius klinikinius atvejus: burnaryklëje [15], nosiaryklëje [16-18], gerklose [19, 20].

Radiologinès diagnostikos atžvilgiu pirmenybè teikiama magnetinio rezonanso tyrimui, tačiau įtariant kaulinę destrukciją, tikslingesnè kompiuterinè tomografija (KT). Būtina atkreipti dèmesį vertinant galimą perineuralinị naviko plitimą, užpakalinị trečdalị kietojo gomurio, sparninę gomurio duobę, foramen ovale. Šios ligos diagnostikos aukso standartas yra pakitusių audinių biopsija ir histologinis audinių ištyrimas [3].

Klasifikacija. Visuotinai pripažintos klasifikacijos, skirtos piktybinei gleivinès melanomai, šiai dienai nèra. $2009 \mathrm{~m}$. sukurta TNM klasifikacija (1, 2 lentelès), skirta viršutinių kvépavimo - virškinimo takų piktybinei gleivinès melanomai [21]. Ivairių autorių duomenimis, ši klasifikacija tiksliausia ir patogiausia kasdienejje klinikineje praktikoje [8, 21-23]. T1-T2 bei I ir II stadijos ị klasifikaciją nèra įtrauktos, norint pabrěžti naviko agresyvumą. Dėmesys sutelktas labiau ị naviko infiltracijos gyli, nei ị pažeistas aplinkines sritis.

Gydymas. GKGM gydymas iki šiolei remiasi odos melanomos gydymo gairemis. Dažniausiai skiriamas didelių dozių interferonas, kuris laikomas pirmos eilès vaistu adjuvantiniam odos melanomos gydymui (I lygmens įrodymas) [24]. II fazès tyrimai parodè, kad pacientams, sergantiems GKGM, interferonas mažiau efektyvus nei chemoterapija kaip adjuvantinis gydymas [24]. Pagrindinis gydymo metodas, nepaisant ịrodymais pagrịstų atsitiktinių imčių tyrimų trūkumo, išlieka chirurgija. Tikslas - radikalus naviko paša- linimas su švariais rezekciniais kraštais [25], kuris atspindi vieną svarbiausių prognozės veiksnių [11, 22, 26]. Autorių teigimu, vertinant endoskopinę ir atvirą chirurgiją, baigtys bei išgyvenamumas reikšmingai nesiskiria [8,27]. Gleivinès melanomai esant žandiniame antyje ir procesui apimant tik medialinę sieną, rekomenduojamas endoskopinis chirurgijos metodas. Pirmenybe teikiama atvirai chirurgijai, kai i navikini procesą įtraukiamas kietasis/ minkštasis gomurys, akiduobès sienos, sparninė gomurio duobė. Šiais atvejais atliekamos medialinès, subtotalinès, totalinès ar radikalios maksilektomijos [9-12, 27]. Akiduobės turinys šalinamas, kai navikinis procesas įtraukia preorbitos audinius. Iki sparninès gomurio duobès šalinami audiniai, kuomet navikinis procesas apima ir užpakalinę sieną. İvairių autorių teigimu, rekomenduojama sveikų audinių riba yra $1,5 \mathrm{~cm}$ spinduliu nuo darinio [11]. Klinikineje praktikoje nustatyta, kad po agresyvių chirurginių intervencijų pacientams melanoma išplinta greičiau. Lund ir bendr. 2012 m. iškèlè hipotezę, teigdami, jog taikant atvirą agresyvią chirurgiją sutrikdoma pusiausvyra imuninejje sistemoje, gal dèl to pasireiškia greitesnis melanomos išplitimas [28].

Metastazavimas. Plitimas ị sritinius limfmazgius labiau būdingas burnos ertmès nei nosies ir prienosinių ančių ertmių gleivinès melanomoms, atitinkamai $25-43$ proc. [29] ir iki 10 proc. [4, 8, 30]. Kai nustatoma didesnè nei $5 \mathrm{~mm}$. burnos ertmès gleivinès infiltracija, ar nustačius mazginị tipą, reikšmingai padideja plitimo ị sritinius limfmazgius rizika [4]. Kai diagnozuojamas mazginis arba makulinis tipas, kurio darinio diametras didesnis nei $4 \mathrm{~cm}$, rekomenduojama kaklo disekcija kartu su biochemoterapija. Pacientams, kuriems nustatomas makulinis tipas ir darinio diametras mažesnis nei $4 \mathrm{~cm}$, rekomenduojama ambulatorinis sekimas [31]. Kaip alternatyva galimas sarginio limfmazgio žymejjimas, pašalinimas ir histologinis ištyrimas [23].

İvairių autorių duomenimis, spindulinè terapija rekomenduojama kaip pooperacinis gydymas naviko ložei ir turetų būti taikomas kiekvienam pacientui (3 lygmens rekomendacija), ypač esant nešvariems rezekciniams kraštams ar ịtariant likusias metastazes limfmazgiuose [32-34]. Spindulinè terapija, kaip pirminis gydymo metodas, rekomenduojama tais atvejais, kai navikas neoperuotinas arba pacientas atsisako chirurginio gydymo (C lygmens rekomendacija) [32-35].

Pastaruoju metu daug dèmesio skiriama hadrono terapijai. Tai spinduline terapija, tačiau naudojami ne rentgeno spinduliai, o sunkieji anglies jonai. Iprastos spindulinès terapijos metu rentgeno spinduliai, pereidami audinius, palaipsniui praranda poveikį. Hadrono terapijos metu poveikis sutelkiamas ị norimą gylị ir koncentruojamas ị tam tikrą norimą vietą "lyg pieštuko smaigalys" [36]. Šiuo metu atliekami klinikiniai bandymai įtraukiant ir operabilius pa- 


\section{6}

cientus [37-39].

Prognozè. Nepaisant rezekcijos radikalumo ar taikytos adjuvantinès terapijos, išlieka didelè atkryčio tikimybè. Vietinis ar tolimas naviko išplitimas nustatomas net 81 proc. pacientų [25]. Blogos prognozės požymiais laikomi: pažengusi T kategorija, nešvarūs rezekciniai kraštai, gili infiltracija, invazija ị stambias kraujagysles, artimujų ar tolimųjų metastazių buvimas [4, 11, 22, 39, 40].

\section{Išvados}

1. Galvos ir kaklo gleivinès melanoma yra retas, agresyvus ir blogos prognozès navikas.

2. Dažniausiai navikas pasireiškia nosies ertmëje, prienosiniuose ančiuose bei burnos ertmejje. Ligos diagnostiką sunkina specifinių simptomų nebuvimas. Vyraujantys nespecifiniai šių lokalizacijų naviko simptomai - nosies obstrukcija, kraujavimas, skausmai veido, burnos srityse.

3. Pagrindinis šios ligos gydymo būdas - radikalus chirurginis. Spindulinè terapija užima pooperacinès terapijos vietą, kontroliuojant lokalų naviko plitimą.

4. Reikia tolimesnių gero dizaino tyrimų, kuriuose būtụ tiriami pacientai, sergantys odos bei galvos ir kaklo gleivinès melanoma.

\section{Literatūra}

1. Mallone S, De Vries E, Guzzo M, Midena E, Verne J, Coebergh JW. et al. Descriptive epidemiology of malignant mucosal and uveal melanomas and adnexal skin carcinomas in Europe. Eur J Cancer 2012;48 (8): 1167-175.

https://doi.org/10.1016/j.ejca.2011.10.004

2. RARECAREnet, 2017. Information Network on Rare Cancers [Internet] [Žiūrèta 2018 spalio 30 d.]. Available from: http:// www.rarecarenet.eu/rarecarenet

3. Lazarev S, Gupta V, Hu K, Harrison LB, Bakst R. Mucosal melanoma of the head and neck: a systematic review of the literature. Int J Radiol Oncol 2014; 90(5): 1108 -118.

https://doi.org/10.1016/j.ijrobp.2014.03.042

4. Patel SG, Prasad ML, Escrig M, Singh B, Shaha AR, Kraus DH. et al. Primary mucosal malignant melanoma of the head and neck. Head Neck 2002; 24 (3): 247-57.

https://doi.org/10.1002/hed.10019

5. Bachar G, Loh KS, O'sullivan B, Goldstein D, Wood S, Brown D. et al. Mucosal melanomas of the head and neck: experience of the Princess Margaret Hospital. Head Neck 2008; 30(10): 1325-331.

https://doi.org/10.1002/hed.20878

6. Mackintosh JA. The antimicrobial properties of melanocytes: melanosomes and melanin and the evolution of black skin. J Theor Biol 2001; 211(2): 101-13.

https://doi.org/10.1006/jtbi.2001.2331
7. Plonka PM, Passeron T, Brenner M, Tobin DJ, Shibahara S, Thomas A. et al. What are melanocytes really doing all day long? Exp Dermatol 2009;18 (9): 799-819.

https://doi.org/10.1111/j.1600-0625.2009.00912.x

8. Moreno MA, Hanna EY. Management of mucosal melanomas of the head and neck: did we make any progress? Curr. Opin. Otolaryngol. Head Neck Surg 2010; 18 (2): 101-106. https://doi.org/10.1097/MOO.0b013e3283374d31

9. López F, Rodrigo JP, Cardesa A, Triantafyllou A, Devaney KO, Mendenhall WM. Update on primary head and neck mucosal melanoma. Head Neck 2016; 38 (1): 147-55.

https://doi.org/10.1002/hed.23872

10. Meleti M, Leemans CR, Mooi WJ, Vescovi P, van der Waal I. Oral malignant melanoma: the Amsterdam experience. J Oral Maxillofac Surg 2007; 65 (11): 2181-186.

https://doi.org/10.1016/j.joms.2006.10.044

11. Penel N, Mallet Y, Mirabel X, Van JT, Lefebvre JL. Primary mucosal melanoma of head and neck: prognostic value of clear margins. Laryngoscope 2006;116 (6): 993-95.

https://doi.org/10.1097/01.mlg.0000217236.06585.a9

12. Tomicic J, Wanebo HJ. Mucosal melanomas. Surg Clin North Am 2003; 83 (2): 237-52. https://doi.org/10.1016/S0039-6109(02)00100-7

13. Tanaka N, Odajima T, Mimura M, Ogi K, Dehari H, Kimijima Y. et al. Expression of Rb: pRb2/p130, p53, and p16 proteins in malignant melanoma of oral mucosa. Oral Oncol 2001; 37 (3): 308-14.

https://doi.org/10.1016/S1368-8375(00)00107-X

14. Sun C, Chen YF, Jiang YE, Hu ZD, Yang AK, Song M. Treatment and prognosis of oral mucosal melanoma. Oral Oncol 2012; 48 (7): 647-52.

https://doi.org/10.1016/j.oraloncology.2012.01.019

15. Wagner M, Morris CG, Werning JW, Mendenhall WM. Mucosal melanoma of the head and neck. Am J Clin Oncol 2008; 31 (1): 43-8.

https://doi.org/10.1097/COC.0b013e318134ee88

16. Thompson LD, Wieneke JA, Miettinen M. Sinonasal tract and nasopharyngeal melanomas: a clinicopathologic study of 115 cases with a proposed staging system. Am J Surg Pathol 2003; 27 (5): 594-611.

https://doi.org/10.1097/00000478-200305000-00004

17. Mardi K. Primary mucosal malignant melanoma of nasopharynx: a rare case report. J Cancer Res Ther 2014;10 (2), 416-18. https://doi.org/10.4103/0973-1482.136676

18. Bekci T, Aslan K, Günbey HP, Incesu L. Primary malignant mucosal melanoma of the nasopharynx: an unusual cause of unilateral hearing loss. J Craniofac Surg 2014; 25 (6): e567-9. https://doi.org/10.1097/SCS.0000000000001165

19. Terada T, Saeki N, Toh K, Uwa N, Sagawa K, Mouri T. et al. Primary malignant melanoma of the larynx: a case report and literature review. Auris Nasus Larynx 2007; 34 (1):105-10. 
https://doi.org/10.1016/j.anl.2006.09.027

20. Zaghi S, Pouldar D, Lai C, Chhetri DK. Subglottic presentation of a rare tumor: primary or metastatic? Primary mucosal melanoma of the subglottic larynx. JAMA Otolaryngol Head Neck Surg 2013;139 (7): 739-40.

https://doi.org/10.1001/jamaoto.2013.3424

21. Sobin LH, Gospodarowicz MK, Wittekind C. (Eds.). 2009. TNM Classification of Malignant Tumours. Wiley-Blackwell [Internet]. Available from: http://www.inen.sld.pe/portal/documentos/pdf/educacion/13072015TNMClassification.pdf.

22. Shuman AG, Light E, Olsen SH, Pynnonen MA, Taylor JM, Johnson TM. et al. Mucosal melanoma of the head and neck: predictors of prognosis. Arch Otolaryngol Head Neck Surg 2011;137 (4): 331-37.

https://doi.org/10.1001/archoto.2011.46

23. Starek I, Koranda P, Benes P. Sentinel lymph node biopsy: a new perspective in head and neck mucosal melanoma? Melanoma Res 2006;16 (5): 423-27.

https://doi.org/10.1097/01.cmr.0000222603.57932.b6

24. Lian B, Guo J. Checkpoint inhibitors in treatment of metastatic mucosal melanoma. Chin Clin Oncol. 2014;3 (3): 37.

25. Michel J, Perret-Court A, Fakhry N, Braustein D, Monestier S, Richard MA. et al. Sinonasal mucosal melanomas: the prognostic value of tumor classifications. Head Neck 2014;36 (3): 311-16.

https://doi.org/10.1002/hed.23298

26. Lee SP, Shimizu KT, Tran LM, Juillard G, Calcaterra TC. Mucosal melanoma of the head and neck: the impact of local control on survival. Laryngoscope 1994; 104 (2): 121-26. https://doi.org/10.1288/00005537-199402000-00001

27. Clifton N, Harrison L, Bradley PJ, Jones N.S. Malignant melanoma of nasal cavity and paranasal antyjes: report of 24 patients and literature review. J Laryngol Otol 2011; 125 (5): 479-85.

https://doi.org/10.1017/S0022215110002720

28. Lund VJ, Chisholm EJ, Howard DJ, Wei WI. Sinonasal malignant melanoma: an analysis of 115 cases assessing outcomes of surgery, postoperative radiotherapy and endoscopic resection. Rhinology 2012; 50 (2): 203-10.

https://doi.org/10.4193/Rhin11.267

29. Tanaka, N., Mimura, M., Kimijima, Y., Amagasa, T. Clinical investigation of amelanotic malignant melanoma in the oral region. J. Oral Maxillofac. Surg 2004; 62(8): 911-917. https://doi.org/10.1016/j.joms.2004.01.017

30. Nakashima JP, Viégas CM, Fassizoli AL, Rodrigues M, Chamon LA, Silva JH. et al. Postoperative adjuvant radiation therapy in the treatment of primary head and neck mucosal melanomas. ORL J Otorhinolaryngol Relat Spec 2008; 80 (6): 344-51. https://doi.org/10.1159/000163029

31. Wu Y, Zhong Y, Li C, Song H, Guo W, Ren G. Neck dissection for oral mucosal melanoma: caution of nodular lesion. Oral
Oncol 2014; 50 (4): 319-24.

https://doi.org/10.1016/j.oraloncology.2014.01.008

32. Wada H, Nemoto K, Ogawa Y, Hareyama M, Yoshida H, Takamura A. et al. A multiinstitutional retrospective analysis of external radiotherapy for mucosal melanoma of the head and neck in Northern Japan. Int J Radiat Oncol Biol Phys 2004; 59 (2): 495-500. https://doi.org/10.1016/j.ijrobp.2003.11.013

33. Combs SE, Konkel S, Thilmann C, Debus J, Schulz-Ertner D. Local high-dose radiotherapy and sparing of normal tissue using intensity-modulated radiotherapy (IMRT) for mucosal melanoma of the nasal cavity and paranasal antyjes. Strahlenther Onkol 2007; 183 (2): 63-8.

https://doi.org/10.1007/s00066-007-1616-2

34. López F, Rodrigo JP, Cardesa A. et al. Update on primary head and neck mucosal melanoma. Head \& Neck 2016; 38(1):147155 .

https://doi.org/10.1002/hed.23872

35. Mizoe JE, Hasegawa A, Jingu K, Takagi R, Bessyo H, Morikawa T. et al. Results of carbon ion radiotherapy for head and neck cancer. Radiother Oncol 2012; 103 (1): 32-7.

https://doi.org/10.1016/j.radonc.2011.12.013

36. Yanagi T, Mizoe JE, Hasegawa A, Takagi R, Bessho H, Onda T. et al. Mucosal malignant melanoma of the head and neck treated by carbon ion radiotherapy. Int J Radiat Oncol Biol Phys 2009; 74 (1): 15-20.

https://doi.org/10.1016/j.ijrobp.2008.07.056

37. Steinsträter O, Grün R, Scholz U, Friedrich T, Durante M, Scholz M. Mapping of RBE-weighted doses between HIMACand LEM-Based treatment planning systems for carbon ion therapy. Int J Radiat Oncol Biol Phys 2012; 84 (3): 854-60.

https://doi.org/10.1016/j.ijrobp.2012.01.038

38. Demizu Y, Fujii O, Terashima K, Mima M, Hashimoto N, Niwa Y. et al. Particle therapy for mucosal melanoma of the head and neck. A single-institution retrospective comparison of proton and carbon ion therapy. Strahlenther Onkol 2014; 190 (2): 186-191.

https://doi.org/10.1007/s00066-013-0489-9

39. Jangard M, Hansson J, Ragnarsson-Olding B. Primary sinonasal malignant melanoma: a nationwide study of the Swedish population, 1960-2000. Rhinology 2013; 51 (1): 22-30.

https://doi.org/10.4193/Rhin12.075

40. Ascierto PA, Accorona R, Botti G, Farina D, Fossati P, Gatta G. et al. Mucosal melanoma of the head and neck. Critical Reviews in Oncology/Hematology 2017; 112: 136-52. https://doi.org/10.1016/j.critrevonc.2017.01.019

\section{MUCOSAL MELANOMA OF HEAD AND NECK: CASE REPORT AND LITERATURE REVIEW}

N.Šiupšinskienė, V.Junčys, E.Padervinskis, S.Norkienė

Key words: mucosal melanoma, head and neck, radiotherapy, surgery, hadron therapy, chemotherapy. 
Summary

Mucosal melanoma of the head and neck is a rare, aggressive malignant tumour with a poor prognosis. 1,3 and 5 years survival rates between 2000 and 2007 were 63, 30 and 20 percent, respectively. The paranasal antyjes, nasal and oral cavities are the most common locations. Clinical signs and symptoms are usually nonspecific. Surgery is considered the main treatment for most mucosal melanomas of the head and neck region. Radiotherapy usually has a role in local control of the disease after surgery. Despite the diffe- rent biology, mucosal melanoma is currently treated in the same way as cutaneous melanoma. Patients with mucosal melanoma were excluded from the majority of recent clinical trials. This article presents a clinical case and a literature review.

Correspondence to: norai_s@yahoo.com

$2018-11-26$ 